\title{
The compositional and biochemical characteristics of traditional Diyarbakir Örgü cheese during the ripening period
}

\author{
Abdulkerim Hatipoglu ${ }^{1}$, and Serafettin Çelik ${ }^{2}$ \\ Received: 28 December 2019 / Accepted: 21 June 2020 / Published online: 10 September 2020 \\ (c) Indian Dairy Association (India) 2020
}

\begin{abstract}
This study was conducted to determine the changes in compositional and various biochemical parameters of traditional Diyarbakir Örgü cheese during storage period. For this purpose, cheese samples were collected from eight different small dairy plants. In this study, it was observed that the composition of the cheese samples during the storage period changed as follows: dry matter decreased from $55.87 \%$ to $52.29 \%$, fat from $26.56 \%$ to $23.47 \%$, fat in dry matter from $38.84 \%$ to $37.07 \%$, protein from $26.56 \%$ to $23.47 \%$; ash increased from $7.31 \%$ to $9.32 \%$, salt from $6.31 \%$ to $8.16 \%$, salt in dry matter from $11.40 \%$ to $15.48 \%$, while the parameters investigated in relation to the biochemical properties of the cheese samples ranged as follows: 18.38-22.96 for $\mathrm{SH}, 5.47-5.64$ for $\mathrm{pH}, 0.17-0.21 \%$ for soluble nitrogen in $\mathrm{pH}$ $4.6,0.03-0.05 \%$ for soluble nitrogen in $12 \%$ TCA, $0.25-0.46 \%$ for lipolysis level and $4.19-5.61 \%$ for ripening index. In this study, the proteolysis level of the cheese during the ripening was determined electrophoretic analysis. According to the Turkish Food Codex Communique on Cheese (Notice No: 2015/6), DÖC is a semi-fat $(25 \leq$ milk fat $<45)$ and hard cheese with the desired moisture content (up to $50 \%$ ) and salt (>7.5\%).
\end{abstract}

Keywords: Biochemical properties, Composition, Diyarbakir Örgü cheese, Pasta-filata cheeses

\footnotetext{
${ }^{1}$ Department of Nutrition and Dietetics, Faculty of Health Sciences, Mardin Artuklu University, Mardin, Turkey

${ }^{2}$ Department of Food Engineering, Faculty of Engineering, Harran University, Sanliurfa, Turkey

Abdulkerim Hatipoglu ( $\square)$

Department of Nutrition and Dietetics, Faculty of Health Sciences, Mardin Artuklu University, Mardin, Turkey

E-mail: abdulkerimhatipoglu@artuklu.edu.tr; Tel: (+90) 4822121395
}

\section{Introduction}

The industrial production and marketing of traditional and regional cheeses are of a great contribution to national economies. Such cheeses are valuable export products for countries such as Germany (3.67 billion dollars), France (3.28 billion dollars) and Italy (2.67 billion dollars) (WTO, 2019). The vast majority of regional cheeses are sold in the region or country they are produced in, for which there are two main reasons. Firstly, traditional cheeses are usually produced in accordance with regional taste and secondly, most of the cheeses produced don't have sufficient marketing opportunities in other countries.

In Turkey, most regional cheeses are produced from raw milk. This increases the risk of infection and intoxication from fresh cheeses caused by pathogenic microorganisms, especially Brucella spp. (Kaynar, 2011; Elmali and Uylaser, 2012; Hatipoglu and Celik, 2012; Kesenkas et al. 2012). Therefore, the production process of regional cheeses should be reevaluated in the context of the pasteurization of the milk and starter culture applications. In addition, cheeses of high quality and economic value should be produced in accordance with the demands of the global market. For this purpose, many studies have been carried out on traditional cheeses (Drake et al. 2001; Hort and Le Grys, 2001; Lawlor et al. 2001; Ritvanen et al. 2001; Singh et al. 2003; Caspia et al. 2006; Kucukoner and Haque, 2006; Uysal, 2008).

Diyarbakir Örgü cheese (DÖC) should be produced industrially while preserving its conventional characteristics (taste, aroma, composition etc.). DÖC is widely consumed in Diyarbakir and surrounding provinces, and is sold just above the cost in markets in cities such as Istanbul, Ankara and Izmir. The production process of DÖC is similar to that of pasta-filata cheeses such as Mozzarella, Caciocavallo and Povola dei Nebrodi. In the production of traditional DÖP, usually raw ewe milk is used. In order to produce the cheese, the milk is coagulated with liquid rennet at $29-30{ }^{\circ} \mathrm{C}$ for $54-70$ minutes in a way that it should coagulate. After the coagulation, the curd which is put in the cheesecloth is pressed and fermented. Cord pulling method is used in order to test whether or not the curd is suitable for scalding. Fermented curd is submerged into the boiler (water, 78$87^{\circ} \mathrm{C}$ ) by placing it in perforated stainless steel pails and scalded 
for 2-7 minutes. The scalded curd dough is placed on the bench, stretched threadlike by cutting in portions of $200 \mathrm{~g}$ on average and shaped as typical braid by weaving. Fresh cheese is left for approximately 20-30 minutes in brine (usually 12 Bé). Then, the cheese is placed into lacquered tin plates or plastic jerry cans and stored at $6 \pm 1{ }^{\circ} \mathrm{C}$ for approximately $4-6$ months by adding 1721 Bé brine. As it matures, the humidity increases and become soften. DÖC is a kind of semi fat and hard cheese (Hatipoglu, 2014, Anoymous, 2015).

DÖC, which is a traditional Anatolian cheese, is produced mostly in the Karacadag Basin situated in the South of the province of Diyarbakir. Due to the small arable areas of the basin and the presence of large meadow-pasture areas, animal husbandry, especially sheep farming, is carried out in general (Hatipoglu and Celik 2012). There were 1164.521 sheep, 157.144 goats and 128.376 cattle (domestic cows, crossbred cows, culture (non-domestic) cows and buffalo) that were being milked in the basin. Approximately 296.000 tons of cattle milk, 97.976 tons of sheep milk and 16.566 tons of goat milk are produced in the basin (Anonymous, 2019).

DÖC production is seasonally performed in portable facilities in the production area (Hatipoglu, 2014). This study is especially important as it is the first study conducted on the ripening characteristics of DÖC. In the present study, the composition and various biochemical properties of DÖC produced in small dairy farms in the Karacadag Basin were investigated.

The composition and maturity of the cheese affects the consumer's nutritional preferences. This study is the first study conducted in the production region of traditional DÖC. The findings of the research may help to standardize and preserve the composition and biochemical properties of the cheese in the industry. Thus, it may provide basic data for the cheese to reach world markets in the near future. In addition, for researchers, this study will provide an insight into the definition and characterization of the composition and biochemical parameters of DÖC as a fieldwork.

\section{Materials and Methods}

The study was conducted in eight small-scale dairy plants, selected upon the suggestion of the Diyarbakir Provincial Directorate of Agriculture and Forestry and local cheese producers. Fresh cheese samples $(4 \mathrm{~kg})$ were collected four times at a week intervals from each dairy plant. The collected cheese samples were stored and ripened at $6 \pm 1{ }^{\circ} \mathrm{C}$ for 6 months.

\section{Composition}

The ratios of dry matter (DM) (gravimetric method) (Anonymous, 1989), fat (butyrometric method) (Anoymous, 1989), ash (gravimetric method) (Anonymous, 1989), salt (Mohr method) (Anonymous, 1989) and protein (Dumas method, by Leco FP
528) (Anonymous, 1989) of the cheese samples were determined on the $1 \mathrm{st}, 30 \mathrm{th}, 60 \mathrm{th}, 90 \mathrm{th}$ and $120 \mathrm{th}$ days of the ripening period.

\section{Biochemical parameters}

Titration acidity (TA) (Dagdemir et al. 2003), pH (WTW 330i, Germany) (Yazici and Dervisoglu, 2003), soluble nitrogen (SN) at pH 4.6 (Dumas method, by Leco FP 528) (Gripon et al. 1975), SN in Trichloroacetic acid (TCA) (Dumas method, by Leco FP 528) (Tavaria et al. 2003) and lipolysis level (Ocak et al. 2015) analyzes were performed on the $1 \mathrm{st}, 30 \mathrm{th}, 45 \mathrm{th}, 60 \mathrm{th}, 90 \mathrm{th}$ and $120 \mathrm{th}$ days of the storage period.

\section{Electrophoresis}

The degradation level of the proteins was determined by the urea-PAGE method in accordance with the density of the protein bands obtained on the $1^{\text {st }}, 30^{\text {th }}, 60^{\text {th }}, 90^{\text {th }}, 120^{\text {th }}, 150^{\text {th }}$ and $180^{\text {th }}$ days of the storage period by using vertical slab-gel electrophoresis (BioRad Laboratories Ltd. Watford, UK). The gels obtained were stained with Comassie Brillant Blue G250 (Blakesley and Boezi 1977; Andrews, 1983; Hynes et al. 1989).

\section{Statistical analysis}

The data obtained were analyzed by the one-way ANOVA and the differences between the significant averages were determined by the Tukey multiple comparison test (Yýldýz \& Bircan, 1994).

\section{Results and Discussion}

\section{Composition}

The ANOVA revealed that there were statistically highly significant $(\mathrm{P}<0.01)$ differences between all compositional parameters (DM, protein, fat, fat in DM, ash, salt and salt in DM) of the cheese samples during storage period (Table 1). The DM, fat and protein ratios of DÖC decreased during the period. In contrast, salt, salt in DM and ash rates increased. The fat in DM rate of the cheese followed a fluctuating course throughout the period and it was determined that this ratio in ripened cheese decreased slightly compared to fresh cheese.

The average DM and protein ratios of commercial Örgü cheese were reported by Ozdemir et al. (1998) as 44.84\% and $21.69 \%$, and as $50.88 \%$ and $21.75 \%$ according to Celik and Turkoglu (2007). Additionally, the average DM and protein ratios of traditional Lavash cheese were reported by Celik et al. (2001) as $45.80 \%$ and $17.52 \%$. The average values of the same components of Cacioricotta cheese were reported by Albenzio et al. (2006) as $46.43 \%$ and $16.8 \%$. Finally, the average DM and protein values of Dil cheese were reported by Uysal (2008) as 53.78\% and $23.95 \%$.

On the other hand, the fat ratios of the samples determined in the study (Table 1) were found to be higher than those reported for 
Örgü cheese by Ozdemir et al. (1998) (\% 14.7) while lower than Örgü (\% 20.6) reported by Celik and Turkoglu (2007) and Dil cheeses (\% 23.64) reported by Uysal (2008) in the literature. As a result of the laboratory analysis, the mean ratio of fat in DM of DÖC was higher than the value (\% 32.23) reported by Ozdemir et al. (1998) for traditional DÖC and lower than those (\% 40.46) reported by Celik and Turkoglu (2007) commercial Örgü cheese and Uysal (2008) (\% 43.96) for Dil cheese.

According to the data obtained from the present study, the average ash and salt ratios of DÖC were determined to be higher than those reported by Ozdemir et al. (1998), Celik and Turkoglu (2007), and Uysal (2008). Similarly, the mean ratio of salt in DM of DÖC obtained in the study were also determined to be higher than that reported for Örgü (\% 9.02 and \% 13.68), Lavash (\% 13.95) and Dil (\% 13.23) cheeses (Ozdemir et al. 1998; Celik et al. 2001; Celik and Turkoglu, 2007; Uysal, 2008).

As seen from the above comparisons, the fact that all of the composition parameters of DÖC (especially DM and fat in DM) were determined to be different from those of other studies may be due to the difference in the race/breed/diet of the dairy animals and the fat content of the raw milk used in the production of the cheeses. Small-scale dairy plants do not only produce DÖC from sheep's milk, they also use cow's and goat's milk (approximately $20 \%$ ). Therefore, they mix the sheep, goat and cow's milk without a fixed rate and produce DÖC from the milk of this mixture. Additionally, it was observed in the local area study that the brines used in the cheese production had different amounts of salt (17-21 Bé) (Hatipoglu, 2014).

Based on the storage period, the average ratio of fat in the DM of DÖC (37.73\%) was determined to be between full-fat cheese (45\%) and fatty cheese (30\%) (Anonymous, 2015; Anonymous, 2006a; Anonymous, 2006b). DÖC is similar to Dil and Kashar cheeses in terms of its production technique and composition properties. Therefore, DÖC can be defined as a fatty cheese based on the cheese standards mentioned above. However, according to the Turkish Food Codex Communique on Cheese, DÖC is considered as a semi-fatty cheese (Anonymous, 2015). DÖC is expected to be a full fat cheese type. However, DÖC cheese and butter fat are also produced at the same time in the Karacadag region. According to the information received in the region, milkfat obtained from milk in the form of cream is used in the production of butterfat, while the remaining partially skimmed milk is used in the cheese production.

As can be seen from Table 1, the ratios of fat, protein and DM of DÖC gradually decreased during the storage period. This may be due to the degradation of proteins and lipids in the cheese matrix by enzymes and microorganisms during the storage period, and may also be due to the low molecular weight compounds formed as a result of the degradation products passing from the cheese into the brine (Grappin and Beuvier, 1997). In addition, it is thought that the amount of salt diffusing from the brine into the cheese matrix is less than the protein and lipid degradation products passing from cheese to brine.

Celik and Turkoglu (2007) reported that the DM ratio of Örgü cheese produced from raw and pasteurized milk decreased significantly during the ripening period. Moreover, the DM ratio of Dil cheese which was produced from raw, thermised, and pasteurized milk and ripened for 90 days in brine, decreased during the 90 day storage period (Uysal, 2008). In addition, Arboatti et al. (2014) reported that the DM ratio of Mozzarella cheese decreased during a 43 days of storage period.

According to the results of the present study (Table 1), the average DM ratio of DÖC $(54.43 \%)$ corresponds to the DM ratio (at least $50 \%$ ) specified in the legislation for Dil cheese.

During the scalding process, there was a positive relationship between the $\mathrm{pH}$ of the curd and the DM level of the DÖC. In contrast, it has been reported that while the $\mathrm{pH}$ of the curd decreased, the DM ratio of the final product increased in a study conducted on Cheddar cheese (Walstra and Jennees, 1984). This can be explained by the decrease in the water binding ability of the curd as the scalding $\mathrm{pH}$ approaches the isoelectric point of casein ( $\mathrm{pH} 4.6)$.

The protein ratio of DÖC decreased significantly $(\mathrm{P}<0.01)$ during the storage period (Table 1). This may be due to the fact that low molecular weight nitrogenous compounds migrated from the cheese matrix into the brine. These values obtained from the

Table 1 The mean values of the composition parameters (\%) of the samples and the groups formed during the storage period $(\mathrm{n}=30)$

\begin{tabular}{|c|c|c|c|c|c|c|c|}
\hline \multicolumn{2}{|c|}{ SP (day) DM } & Protein & Fat & Fat in DM & Ash & Salt & Salt in DM \\
\hline$\overline{1}$ & $55.44 \pm 1.13^{\mathrm{a}}$ & $26.56 \pm 0.64^{a}$ & $21.56 \pm 0.80^{a}$ & $38.84 \pm 0.99^{a}$ & $7.31 \pm 0.33^{c}$ & $6.31 \pm 0.27^{c}$ & $11.40 \pm 0.52^{\mathrm{e}}$ \\
\hline 30 & $55.32 \pm 1.13^{\mathrm{a}}$ & $25.84 \pm 0.64^{b}$ & $20.71 \pm 0.80^{b}$ & $37.38 \pm 0.99^{b c}$ & $8.77 \pm 0.33^{b}$ & $7.70 \pm 0.27^{b}$ & $13.95 \pm 0.52^{d}$ \\
\hline 60 & $54.75 \pm 1.13^{\mathrm{a}}$ & $25.23 \pm 0.64^{\mathrm{c}}$ & $20.33 \pm 0.80^{b c}$ & $37.07 \pm 0.99^{c}$ & $9.19 \pm 0.33^{\mathrm{a}}$ & $8.04 \pm 0.27^{\mathrm{a}}$ & $14.72 \pm 0.52^{\mathrm{c}}$ \\
\hline 120 & $52.84 \pm 1.13^{\mathrm{c}}$ & $23.47 \pm 0.64^{\mathrm{e}}$ & $20.06 \pm 0.80^{\mathrm{c}}$ & $37.88 \pm 0.99^{b}$ & $9.32 \pm 0.33^{\mathrm{a}}$ & $8.16 \pm 0.27^{\mathrm{a}}$ & $15.48 \pm 0.52^{\mathrm{a}}$ \\
\hline Mean & $54.43 \pm 1.13$ & $25.20 \pm 0.64$ & $20.57 \pm 0.80$ & $37.73 \pm 0.99$ & $8.77 \pm 0.33$ & $7.67 \pm 0.27$ & $14.13 \pm 0.52$ \\
\hline
\end{tabular}

Means with different letters in the same column are significantly different $(\mathrm{P}<0.01)$. SP: Storage period; DM: Dry matter 
study were higher than the protein ratios reported for Örgü (Akyuz et al. 1998; Ozdemir et al. 1998; Turkoglu et al. 2003; Celik et al. 2006 Celik andTurkoglu, 2007), Lavash (Celik et al. 2001) and Dil cheeses (Uysal, 2008). Furthermore, in another study in the literature, it was reported that the protein content in Kaskaval cheese was reduced during a storage period of 56 days (Andronoiu et al. 2015).

The average fat content of DÖC decreased significantly $(\mathrm{P}<0.01)$ during the ripening period (Table 1). This may be due to the breakdown of the products resulting from the hydrolysis of the lipids passing into the brine (Grappin and Beuvier, 1997).

The average fat ratio of DÖC was determined as $21.56 \%$ and $20.06 \%$ on the $1^{\text {st }}$ and $120^{\text {th }}$ days of the ripening period, respectively. These values are similar to the fat ratio determined in a study on Örgü cheese which matured for 90 days in brine (Celik and Turkoglu, 2007). This study reported that the amount of fat in Örgü cheese produced from raw and pasteurized milk decreased significantly $(\mathrm{P}<0.05)$ during the ripening period. In the survey studies, different researchers reported that the average fat ratios of Örgü cheese were between 14.72-17.86\% (Ozdemir et al. 1998; Akyuz et al. 1998; Turkoglu et al. 2003). Similarly, it was reported that fat content in Kaskaval cheese decreased during the storage period (Andronoiu et al. 2015).

Although the ratio of fat in DM changed irregularly, decreases in the matured (120 days) cheese compared to fresh (1 day) cheese were observed during the ripening period of DÖC (Table 1). On the $120^{\text {th }}$ day of the ripening period (in mature cheese), the fat ratio in DM was determined as $37.88 \%$. This value is lower than the value reported by Celik and Turkoglu (2007) for Örgü cheese while it is higher than the values reported by Ozdemir et al. (1998) and Aksu et al. (1999). This difference may be due to the fat content of the milk used in the cheese production, the temperature and duration of the scalding prosess of the fermented curd.

The ash ratio of DÖC increased until the $60^{\text {th }}$ day of the ripening period and then reached equilibrium (Table 1). This was parallel to the salt passing to DÖC and caused by the increase in the salt ratio. The ash ratio was determined as $7.31 \%$ on the first day of the period and as $9.32 \%$ at the end of the period (120th day). Various studies reported that the ash ratio of Örgü cheese ranged from $6.43 \%$ to $8.01 \%$ (Akyuz et al. 1998; Ozdemir et al. 1998; Aksu et al. 1999; Turkoglu et al. 2003;). The ash ratio of Dil cheese matured for 90 days was reported as $5.18 \%$ on the first day and as $5.98 \%$ on the last day (Uysal, 2008). It was reported in another study that the ash ratio of the Caciocavallo cheese ripened in brine for 150 days was $3.84 \%$ in fresh cheese and it continuously increased to $5.50 \%$ in the mature $\left(150^{\text {th }}\right.$ day) cheese (Perna et al. 2014).

At the beginning of the storage period, due to the very high difference between the salt content of fresh cheese and the brine, the salt proportion of the DÖC samples increased rapidly until the $30^{\text {th }}$ day of the period which continued until the $60^{\text {th }}$ day. On the $60^{\text {th }}$ day of the storage period, the salt's transition to cheese was balanced (Table 1). Similarly in a study by Arboatti et al. (2014), it was reported that the increase in the salt content of the Mozzarella cheese matured in brine during the storage period. On the other hand, the salt ratio of Örgü cheese were reported as 5.32-6.03\% in another studies (Ozdemir et al. 1998; Akyuz et al. 1998; Turkoglu et al. 2003). In addition, the salt ratio of the Maras finger cheese maturated in brine was reported as 5.3\% (Tekinsen, 1996). In a study, the average salt ratios of 90 -day old Dil cheeses produced from raw, thermised and pasteurized milk were reported as 5.02, 4.80 and 5.12, respectively (Uysal, 2008). In the present study, the average salt ratio of the cheese was $8.16 \%$ on the $120^{\text {th }}$ day of the storage period. This could be caused by the high salt content in the brines (17-21 Bé) used by the plants that were the subject of the study. The ratio of salt in DM increased gradually during the ripening period (Table 1). At the end of this period, the average ratio of the salt in the DM of DÖC was determined as $15.48 \%$. It was reported in another study that this ratio was between $13.77-15.66 \%$ at the end of a 90 -day storage period of Örgü cheese produced from raw and pasteurized milk (Celik et al. 2006). Various studies reported that the ratio of the salt in the DM of Örgü cheese was between 10.02-14.12\% (Ozdemir et al. 1998; Akyuz et al. 1998; Aksu et al. 1999). The ratios of salt in DM were measured as $9.49 \%, 9.12 \%$ and $9.72 \%$ for mature (90th days) Dil cheese made from raw, thermized and pasteurized milk, respectively (Uysal, 2008).

According to the Turkish Food Codex Communique on Cheese, this value should be $7.5 \%$ at the most. Therefore, based on reference, it can be said that the average ratio of salt in DM of the DÖC was high in the present study (Table 1). However, this is due to the fact that the Dil cheese specified in Turkish standards, namely TS 3002, applies to cheese made from pasteurized milk, and because it is considered as a fresh cheese that is freshly consumed without being ripened in brine. Nowadays, the tendency to present cheeses such as Kashar, Örgü, Dil and Lavash, the fermented curd of which is scalded at high temperatures, for fresh consumption after packaging under vacuum has increased. At the same time, it is known that all of the mentioned cheese varieties (except Kashar) are mostly offered for consumption after being ripened in brine. These cheeses, which are semi-hard, have a high salt content due to their maturation in the brine that contains high amounts of salt.

\section{Biochemical parameters}

The difference between biochemical parameters of DÖC were found to be highly significant $(\mathrm{P}<0.01)$ in terms of storage period. The TA value of the DÖC fluctuated during the storage period (Table 2). 
This was also reported in similar studies in the literature (Uysal, 2008; Celik and Turkoglu, 2007; Tarakci and Kucukoner, 2006). The mean TA value decreased up to the $45^{\text {th }}$ day of the storage period and then increased (Table 2). On the $45^{\text {th }}$ day of the period, the average TA value of the DÖC was the lowest $(18.38 \mathrm{SH})$ and the highest mean TA value $(22.96 \mathrm{SH})$ was seen on the $120^{\text {th }}$ day of the period. It was reported that alkaline and neutral compounds caused by proteolysis and free acids formed as a result of lipolysis can lead to a decrease in TA (Uysal, 2008; Guven and Konar, 1997). In addition, it was reported that the acidity of the cheese is caused by lactic acid, acetic acid, butyric acid, formic acid, free fatty acids resulting from lipolysis and free amino acids formed as a result of proteolysis (Yilmaztekin, 2001).

In the present study, the mean TA value was determined as 20.35 SH (Table 2). Celik and Turkoglu (2007) reported the average TA value of Örgü cheese made from raw milk and pasteurized milk which was followed by a fluctuating course during a 90 day ripening period was determined as $22.28 \mathrm{SH}$ and $21.14 \mathrm{SH}$, respectively. This study revealed that TA increased until the $30^{\text {th }}$ day and decreased after the $60^{\text {th }}$ day. Furthermore, Uysal (2008) reported the TA of Dil cheese made from raw milk decreased until the $30^{\text {th }}$ day of the ripening period and then started to increase. According to the results of studies conducted by various researchers on Dil, Örgü and Lavash cheeses, the mean TA values were found to be $22.89 ; 22.86,15.11,49.33 ; 22.74$, respectively (Ozdemir et al. 1998; Celik et al. 2001; Turkoglu et al. 2003; Aksu et al. 1999; Kocak et al. 1997).

According to the relevant standard, the highest value of TA of the Dil cheese is $1.0 \% \mathrm{LA}(44.44 \mathrm{SH})$. During the ripening period in the present study, the DÖC samples were determined to be in compliance with this standard (Anonymous, 2006a).

The average $\mathrm{pH}$ values of the DÖC samples increased until the $30^{\text {th }}$ day of the storage period and started to decrease after the $60^{\text {th }}$ day. This increase in the $\mathrm{pH}$ of the samples may be due to the formation of alkaline compounds as a result of proteolysis, and the decrease starting from the $60^{\text {th }}$ day may be caused by the rapid increase in the lipolysis level. It was reported that the $\mathrm{pH}$ values of the Örgü cheese increased up to the $15^{\text {th }}$ day of the ripening period and then decreased until the end of the period (Celik and Turkoglu, 2007). In another study, it was reported that the average $\mathrm{pH}$ values of Dil cheese increased up to the $60^{\text {th }}$ day of the ripening period and decreased relatively on the $90^{\text {th }}$ day of the period (Uysal, 2008). "In addition, it was stated that the $\mathrm{pH}$ of Mozzarella fluctuated during 43 days of storage (Arboatti et al. 2014). Similarly, it was reported that the $\mathrm{pH}$ values of Kashkaval cheese which was stored for 180 days fluctuated between 5.0-5.3 (Pappa et al. 2019). A similar result was stated for the Caciocavallo cheese which was matured for 150 days (Perna et al. 2014). Celik and Turkoglu (2007) reported the average pH of Örgü cheese made from raw milk and pasteurized milk was 5.07 and 5.08, respectively. In their study, Anar et al. (2000) reported that the average $\mathrm{pH}$ of Örgü cheese was 5.30. Uysal (2008) reported that the average $\mathrm{pH}$ values of Dil cheese made from raw, thermised and pasteurized milk were 5.07, 5.14 and 5.19, respectively. In a survey study, the average acidity of Dil cheese was expressed as $5.20 \mathrm{pH}$ (Kocak et al. 1997). According to the results of the present study, the average $\mathrm{pH}$ of DÖC was higher than the values reported in the studies mentioned above.

The average lipolysis values of the DÖC samples (Table 2) were lower than the values of Örgü cheese made from raw and pasteurized milk (1.49 and $1.27 \mathrm{mg} \mathrm{KOH} / \mathrm{g}$-fat) reported by Celik and Turkoglu (2007), and higher than the values of the Dil cheese made from raw, thermised and pasteurized milk $(0.25,0.22$ and $0.34 \mathrm{mg} \mathrm{KOH} / \mathrm{g}$-fat) determined by Uysal (2008).

In the present study, the lipolysis value of DÖC increased significantly $(\mathrm{P}<0.01)$ during the storage period (Table 2$)$. The average lipolysis value of DÖC was $0.25 \mathrm{mg} \mathrm{KOH} / \mathrm{g}$-fat on the first day of the ripening period, while it was $0.46 \mathrm{mg} \mathrm{KOH} / \mathrm{g}$-fat on the $120^{\text {th }}$ day of the period. Similarly, various studies reported that the lipolysis values of Örgü and Dil cheeses increased significantly $(\mathrm{P}<0.05)$ during the 90 -day storage period (Uysal, 2008; Celik and Turkoglu, 2007). It has been stated that the level of lipolysis in the cheese matured in brine was affected by the

Table 2 The mean values of various biochemical parameters of DOC and the groups formed during the storage period $(\mathrm{n}=30)$

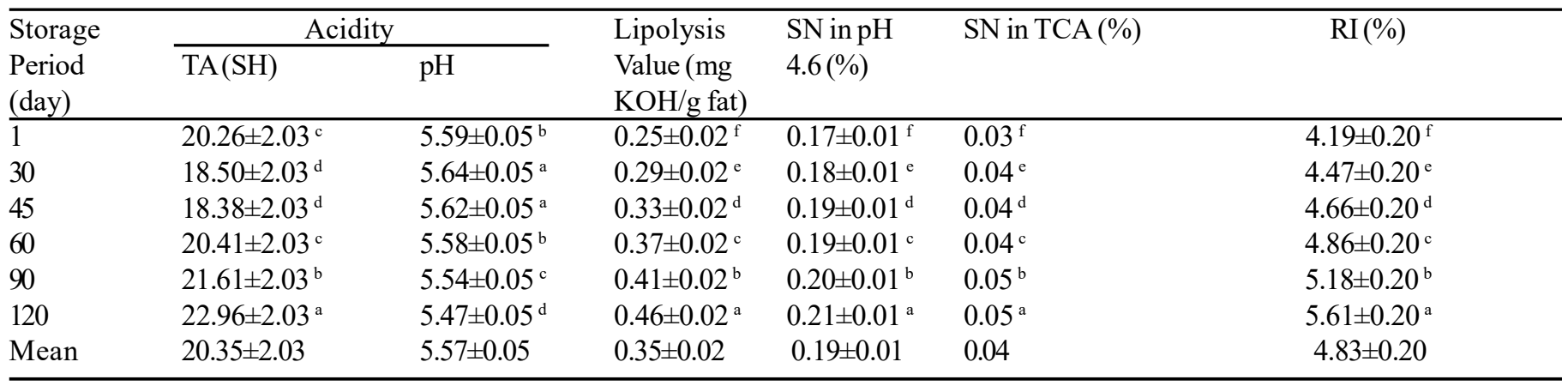

Means with different letters in the same column are significantly different $(\mathrm{P}<0.01)$. TA: Titration acidity ( $\mathrm{SH})$, $\mathrm{SN}$ : Soluble nitrogen, TCA: $12 \%$ Trichloroacetic acid, RI: Ripening index 
Fig. 1 Urea-PAGE electrophoretogram of DÖC during the storage period

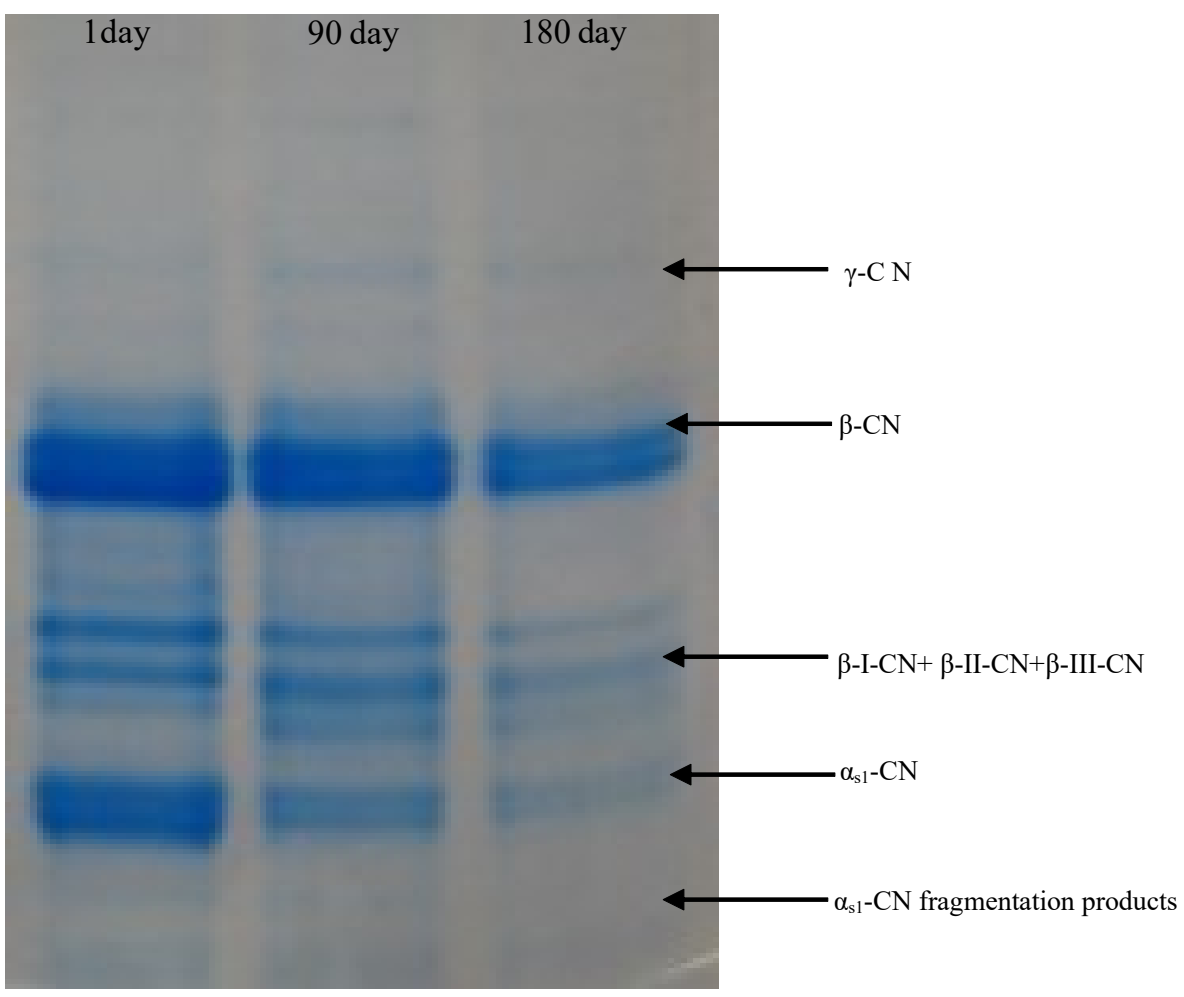

origin of the milk used in production, milk pasteurization, milk lipase, bacterial lipase, brine concentration and maturation temperature (Abd El-Salam, 1987). Moreover, Fox et al. (2000) reported that most of the proteinase enzymes synthesized by psychrotrophic bacteria dissolved in water was removed by whey while most of the psychrotrophic lipase enzymes were temperature-resistant and caused rancidity during the storage period. As a result of the activities of these enzymes, an increase in the lipolysis value of the cheeses was observed in the present study (Table 2).

According to the results of this study, the average ratio of SN in $4.6 \mathrm{pH}$ of DÖC was higher than the values reported for Dil cheese (Uysal, 2008). The difference between SN in pH 4.6 for different cheeses may be caused by the different microflora of the milk used by each plant.

The average values of SN in pH 4.6 of the DÖC samples showed an increase during the 120 days of ripening period (Table 2). Similarly, it was reported that the average ratio for $\mathrm{SN}$ in $\mathrm{pH} 4.6$ of Dil cheese made from raw milk was $0.13 \%$ in fresh cheese (day 1 ) and $0.14 \%$ in mature cheese (day 90) (Uysal, 2008). There is a positive correlation between $\mathrm{SN}$ in $\mathrm{pH} 4.6$ and $\mathrm{SN}$ in TCA values. It has been determined that monitoring the changes in the ratio of these two parameters in cheese gives information about the degree of maturation (Uysal, 2008; Fox et al. 2000).

As can be seen from Table 2, there was a continuous increase in the rate of the average SN in TCA of the DÖC during the storage period. Celik and Turkoglu (2007) reported that the average ratio of SN in TCA in Örgü cheese made from raw milk and pasteurized milk increased during the 90-day storage period. On the other hand, Uysal (2008) stated that SN in TCA of Dil cheese made from raw milk did not change until the $30^{\text {th }}$ day of the ripening period and that SN in TCA values of Dil cheeses which were made from thermised milk and pasteurized milk remained constant until the $60^{\text {th }}$ day of the storage perod while these values increased slightly on the following days. Studies have reported that the ratio of SN in TCA of Kasseri, Caciocavallo and Kashkaval cheeses produced from raw milk were higher than the values of DÖC. However, Kashar cheese produced from raw milk and pasteurized milk showed no difference in terms of this parameter (Sert et al. 2007; Moatsou et al. 2011; Perna et al. 2014; Pappa et al. 2019).

The RI value increased parallel to the protein degradation in DÖC matrix during the storage period (Fig 1). According to the data obtained from this study, the average RI of DÖC was calculated as $4.83 \%$. Tarakci and Kucukoner (2006) reported that the RI of Kashar cheese was between $10.50-10.59 \%$ in fresh cheese ( 5 days) and between $20.95-18.70 \%$ in mature cheese $(90$ days). In addition, the RI of fresh ( 2 days) herby cheese was reported as $5.75 \%$ and as $13.57 \%$ for the mature (90 days) cheese (Tarakci et al. 2005). Arboatti et al. (2014) calculated the RI of 43day (mature) Mozzarella cheese as $3.87 \%$. In the survey studies, the RI of Dil, Örgü and Lavash cheeses were reported as 12.45, 3.09 and 2.30\%, respectively (Kocak et al. 1997; Ozdemir et al. 1998; Celik et al. 2001). 


\section{Electrophoresis}

The density of the bands representing the $\alpha_{\mathrm{s} 1}$-Cn was relatively low compared to the bands representing the $\beta$-Cn on the electrophoretogram of the DÖC samples (Fig 1). This can be explained by the chymosin activity which was higher than the plasmin activity in the cheese curd (Mcsweeney and Sousa, 2000). Similarly, chymosin is also known to hydrolyse $\alpha_{\mathrm{s} 1}-\mathrm{Cn}$ (Creamer and Mills, 1971; Creamer, 1976). And this situation confirms resistance of $\beta-\mathrm{CN}$ to chymosin hydrolysis as reported by Fox et. al. (1993). Due to the high salt concentration (17-21 Bé) of the brine, it was estimated that the activity of plasmin decreased and $\beta$-Cn degradation slowed down (Fallico et al. 2005). Similar results were also reported for different types of cheeses (Milanovic et al. 1998; Saldamli and Kaytanli, 1998; Katsiari et al. 2000; Pavia et al. 2000; Gobbetti et al. 2002; Kongo et al. 2009).

On the other hand, it has also been reported that high scalding temperature, high $\mathrm{pH}$ and low moisture level decrease the chymosin activity in the cheese matrix, while they increase the enhancing effect of plasmin activity on $\beta$-Cn (Singh et al. 2003; Kelly et al. 1996; Sousa et al. 2001). The electrophoretogram of the DÖC samples showed that $\gamma-\mathrm{Cn}$ was formed from $\beta-\mathrm{Cn}$ (Figure 1). This revealed that plasmin activity existed in the cheese ( $\mathrm{Di}$ Cagno et al. 2003). Plasmin activity is also known to be an important parameter in the differentiation of cheese varieties (Sousa et al. 2001).

Furthermore, Carretero et al. (1994) reported that these breakdown products emerged in cheese made from goat's milk. In addition, the effect of bacteria on the level of proteolysis in cheese was expressed (Fox, 1989). Although starter culture was not used in the production of DÖC, non-starter lactic acid bacteria in natural flora of the milk can also increase the level of proteolysis of the cheese.

\section{Conclusions}

Since DÖC is not produced within a certain standard, the fat in $\mathrm{DM}$, salt in DM and DM contents of the cheese should be standardized. In addition, in order to reduce the salt content of the cheese mass, keeping DÖC in vacuum packages instead of preserving it in brine with high salt content is a more suitable option. According to the Turkish Food Codex Communique on Cheese (Notice No: 2015/6), DÖC is a semi-fat ( $25 \leq$ milk fat $<45$ ) and hard cheese with the desired moisture content (up to $50 \%$ ) and salt (>7.5\%). Until now, industrially produced cheeses under the name of "Örgü cheese" did not represent the traditional characteristics of DÖC. For this reason, the demand for this cheese could not be met sufficiently. In conclusion, it is thought that adopting the cheese to the dairy industry without losing its natural characteristic properties will gain more importance in the near future.

\section{Acknowledgement}

This study was supported by Harran University's Scientific Research Projects Coordinatorship (HUBAK Project No: 12019).

\section{References}

Abd El-Salam MH (1987) Domiati and feta type cheeses. cheese: Chemistry, physics and microbiology. In: PF Fox (ed) London, Elsevier Appl Sci, pp 277-309

Aksu H, Colak H, Vural A, Erkan ME (1999) A Research on microbiological and chemical properties of knitted cheese produced in Diyarbakir region. J Yizüncü Yil Uni Vet Med Fac 10: 8-11

Akyuz N, Tutsi MF, Mengel Z, Ocak E, Altun I (1998) Production technique of knitting cheese, some microbiological and chemical properties. milk and dairy products symposium traditional dairy products. National Productivity Center Publications, Tekirdad, Turkey, pp 328-337

Albenzio M, Caroprese M, Marino R, Muscio A, Santillo A, Sevi A(2006) Characteristics of Garganica goat milk and cacioricotta cheese. Small Rum Res 64: 35-44. doi:10.1016/j.smallrumres.2005.03.010

Anar S, Soyutemiz E, Cetinkaya F (2000) Investigation on the microbiological and chemical changes of Örgü cheese at different production stages. J Uludag Uni Vet Med Fac 19: 81-85

Andrews AT (1983) Proteinases in normal bovine milk and their action on caseins. J Dairy Res 50: 45-55. doi:10.1017/S0022029900032519

Andronoiu DG, Botez E, Nistor OV, Mocanu GD (2015) Ripening process of Cascaval cheese: compositional and textural aspects. J Food Sci Technol 52: 5278-5284. doi:10.1007/s13197-014-1621-2

Anonymous (1989) The standard of beyaz cheese. Turkish Standardization Institute (TS 591). Ankara, Turkey

Anonymous (2006a) The standard of dil cheese. Turkish Standardization Institute, T.S. 3002. Ankara, Turkey

Anonymous (2006b) The standard of kashar cheese. Turkish Standardization Institute, T.S. 3272. Ankara, Turkey

Anonymous (2015) Turkish food codex communique on cheese (Notice No: 2015/6). Turkish Official Newspaper, 25 February 2015 No:29261.https://www.resmigazete.gov.tr/eskiler/2015/02/ 20150208-16.htm. Accessed 15 September 2019.

Anonymous (2019) Turkish Statistical Institute

Arboatti AS, Olivares ML, Sabbag NG, Costa SC, Zorrilla SE, Sihufe GA (2014) The influence of sodium chloride reduction on physicochemical, biochemical, rheological and sensory characteristics of Mozzarella cheese. Dairy Sci Technol 94: 373386. doi: 10.1007/s13594-014-0169-2

Beuvier E, Berthaud K, Cegarra S, Dasen A, Pochet S, Buchin S, Duboz G (1997) Ripening and quality of Swiss-type cheese made from raw, pasteurized or microfiltered milk. Int Dairy J 7: 311-323. doi: 10.1016/S0958-6946(97)00015-0

Blakesley RW, Boezi JA (1977) A New staining technic for proteins in polyachrilamide gel using comassie brillant blue G250. Anal Biochem 82: 580-582. doi:10.1016/0003-2697(77)90197-x

Calvo MV, Castillo I, Diaz-Barcos V, Requena T, Fontecha J (2007) Effect of a hygienized rennet and a defined strain starter on proteolysis, texture and sensory properties of semi-hard goat cheese. Food Chem 102:917-924. doi: 10.1016/j.foodchem.2006.06.028

Carretero C, Trujillo AJ, Montserrat MM, Pla R, Guamis B (1994) Electrophoretic study of casein breakdown during ripening of goat's milk cheese. J Agric Food Chem 42:1546-1550. doi:10.1021/ jf00043a029

Caspia EL, Coggins PC, Schilling, MW, Yoon Y, White CH (2006) The relationship between consumer acceptability and descriptive sensory 
attributes in cheddar cheese. J Sensory Stud 21: 112-127. doi:10.1111/ j.1745-459X.2006.00054.x

Celik S, Ozdemir C, Ozdemir S (2001) Production techniques and some properties of traditional lavas cheese. J Biol Sci 1: 603-605. doi: 10.3923/jbs.2001.603.605

Celik S, Turkoglu H, Erdogan A (2006) Composition and variation of some biochemical properties during the maturation period of traditional orgu cheese made from pasteurized milk containing different rates of fat. Turkey 9. Food Congress, Bolu, pp 867-868

Celik S, Turkoglu H (2007) Ripening of Orgu cheese manufactured with raw or pasteurized milk: Composition and biochemical properties. Int J Dairy Technol 60: 253-258. doi:10.1111/j.14710307.2007.00344.x

Creamer LK, Mills OE (1971) The action of rennets on the caseins, rennin action on â-casein in solution. J Dairy Res 38: 269-280. doi: $10.1017 / \mathrm{S} 0022029900019385$

Creamer LK (1976) A further study of the action of rennin on â-casein. New Zeland J Dairy Sci Technol 11: 30-39

Dagdemir E, Celik S, Ozdemir S (2003) The effects of some starter cultures on the properties of Turkish White cheese. Int J Dairy Technol 56: 215-218. https://doi.org/10.1046/j.1471-0307.2003.00103.x

Di Cagno R, Banks J, Sheezhan L, Fox PF, Brechany EY, Corsetti A, Gobbetti M (2003) Comparison of the microbiological, compositional, biochemical, volatile profile and sensory characteristics of three Italian PDO Ewes' milk cheeses. Int Dairy J 13: 961-972. doi: 10.1016/S0958-6946(03)00145-6

Drake MA, Mcingvale SC, Gerard PD, Cadwallader KR, Civille GV (2001) Development of a descriptive language for cheddar cheese. J Food Sci 66:1422-1427. doi:10.1111/j.1365-2621.2001.tb15225.x

Elmali G, Uylaser V (2012) Production and properties of chechil cheese as a traditional food. J Uludag Uni Agric Fac 26: 83-92

Fallico V, Mcsweeney PLH, Horne J, Pedilliggieri C, Hannon JA, Carpino S, Licitra G (2005) Evaluation of bitterness in Ragusano cheese. J Dairy Sci 88: 1288-1300. doi:10.3168/jds.S0022-0302(05)727958

Fox PF (1989) Proteolysis during cheese manufacture and ripening. J Dairy Sci 72:1379-1400. doi:10.3168/jds.S0022-0302(89)792468

Fox PF, Guinee TP, Cogan TM, Mcsweeney PLH (2000) Fundamentals of Cheese Science. Maryland: Aspen Publishers. p. 638.

Fresno M, Alvarez S (2012) Chemical, textural and sensorial changes during the ripening of Majorero goat cheese. Int J Dairy Technol 65: 393-400. doi:10.1111/j.1471-0307.2012.00842.x

Gaya P, Medina M, Rodriguez-Marin MA, Nuñez M (1990) Accelerated ripening of ewes' milk Manchego cheese: The effect of elevated ripening temperatures. Dairy Sci 73(1):26-32. doi:10.3168/ jds.S0022-0302(90)78641-9

Gobbetti M, Morea M, Baruzzi F, Corbo MR, Matarante A, Considine T, Di Cagno R, Guinee T, Fox PF (2002) Microbiological, compositional, biochemical and textural characterisation of caciocavallo Pugliese cheese during ripening. Int Dairy J 12:511523. doi: 10.1016/S0958-6946(02)00042-0

Grappin R, Beuvier E (1997) Possible implications of milk pasteurisation on the manufacture and sensory quality of ripened cheese. Int Dairy J 7: 751-761. doi:10.1016/S0958-6946(98)00006-5

Gripon JC, Desmazeaud MJ, Le Bars D, Bergere JL (1975) Etude du role des micro-organismens et des enzymes au cours de la maturation des fromages. Le Lait 548: 502-516. doi: 10.1051/lait:197554828

Guven M, Konar A (1997) Effects of Cumin Usage and Ripening Periods on the Chemical and Organoleptical Quality of Altenburger Cheese. J Çukurova Uni Agric Fac 12: 69-78.
Hatipoglu A, Celik S (2012) Traditional cheese produced in Karacadag basin in Diyarbakir province and problems encountered. 3. Traditional Foods Symposium, pp 89-92

Hatipoglu A (2014) Characteristic properties of the traditional Diyarbakir Orgu cheese and evaluation in terms of the food safety, $\mathrm{PhD}$ Thesis submitted to Science Institute (Harran University), Sanliurfa, Turkey

Hort J, Le Grys G (2001) Developments in the textural and rheological properties of UK cheddar cheese during ripening. Int Dairy J 11: 475-481. doi: 10.1016/S0958-6946(01)00074-7

Hynes E, Delacroix-Buchet A, Meinardi CA, Zalazar CA (1989) Relationship between $\mathrm{pH}$, degree of proteolisis and consistency in soft cheese. Australian J Dairy Tecnol 54:24-27.

Katsiari MC, Alichanidis E, Voutsinas LP, Roussis IG (2000) Proteolysis in reduced sodium feta cheese made by partial substitution of $\mathrm{NaCl}$ by KCl. Int Dairy J 10: 635-646. doi: 10.1016/S0958-6946(00)000972

Kaynar P (2011) Microbiological research on Turkish cheese. Turkish J Microbiol Commun 41:1-8. doi:10.5222/TMCD.2011.001

Kelly M, Fox PF, Mcsweeney PLH (1996) Effect of salt-in-moisture on proteolysis in cheddar-type cheese. Milchwissenshaft 51: 498-501

Kesenkas H, Dinkci N, Kinik O (2012) Properties of Köy cheeses produced in different dairies. J Ege Uni Agric Fac 49:167-173

Kocak C, Aydinoglu G, Uslu K (1997) A Research on proteolysis level of dil cheeses marketed in Ankara. Food J 22: 251-255.

Kongo JM, Gomes AM, Malcata FX, Mcsweeney PLH (2009) microbiological, biochemical and compositional changes during ripening of Sao Jorge- a raw milk cheese from the Azores (Portugal). Food Chem 112:131-138. doi: 10.1016/j.foodchem.2008.05.067

Kucukoner E, Haque ZU (2006) Physicochemical properties of low-fat and full-fat cheddar cheeses. Int J Dairy Technol 59:166-170. doi: 10.1111/j.1471-0307.2006.00240.x

Lawlor JB, Delahunty CM, Wilkinson MG, Sheehan J (2001) Relationships between the sensory characteristics, neutral volatile composition and gross composition of ten cheese varieties. Le Lait 81(4):487507. doi:10.1051/lait:2001147

Mcsweeney, PLH. \& Sousa, MJ. (2000). Biochemical pathways for the production of flavour compounds in cheeses during ripening: A Review. Le Lait 80: 293-324. doi:10.1051/lait:2000127

Mcsweeney PLH, Fox PF, Lucey JA, Jordan KN, Cogan TM (1993) Contribution of the indigenous microflora to the maturation of cheddar cheese. Int Dairy J 3: 613-634. doi: 10.1016/09586946(93)90104-8

Milanovic S, Kalab M, Caric M (1998) Structure of kaskaval curd manufactured from milk of UF retentate using enzymes of various origin. Lebensmittel Wissenschaft und Technologie 31: 377-386. doi: 10.1006/fstl.1998.0374

Moatsou G, Kandarakis I, Moschopoulou EI, Anifantakis E, Alichanidis E (2011) Effect of technological parameters on the characteristics of kasseri cheese made from raw or pasteurized ewes' Milk. Int J Dairy Technol 54: 69-77. doi: 10.1046/j.1471-0307.2001.00010.x

Ocak E, Tuncturk Y, Javidipour I, Kose S (2015) Changes occurring during maturation in Van Herbed cheese produced from different milk types: Microbiological changes, lipolysis and free fatty acids. Yüzüncü Yil Uni J Agric Sci 25:164-173. doi: 10.29133/yyutbd.236402

Ozdemir S, Celik S, Ozdemir C, Sert S (1998) Microbiological and chemical properties of Orgu cheese made in Karacadag region of Diyarbakir. V. Milk and Dairy Products Symposium, Tekirdag, Turkey, pp 154166

Pappa EC, Kondyli E, Samelis J (2019) Microbiological and biochemical characteristics of Kashkaval cheese produced using pasteurised or raw milk. Int Dairy J 89: 60-67. doi:10.1016/j.idairyj.2018.08.011 
Pavia M, Trujillo AJ, Guamis B, Ferragut V (2000) Proteolysis in manchegotype cheese salted by brine vacuum impregnation. J Dairy Sci 83:1441-1447. doi: 10.3168/jds.S0022-0302(00)75014-4

Perna A, Simonetti A, Intaglietta I, Gambacorta E (2014) Effects of genetic type, stage of lactation, and ripening time on Caciocavallo cheese proteolysis. J Dairy Sci 97:1909-1917. doi:10.3168/jds.20137288

Ritvanen T, Lampolahti S, Lilleberg L, Tupasela T, Isoniemi M, Applebye U, Lyytikäinen T, Eerola S, Uusi-Rauva E (2005) Sensory evaluation, chemical composition and consumer acceptance of full fat and reduced fat cheeses in the finnish market. Food Qual Pref 16: 479492. doi:10.1016/j.foodqual.2004.10.001

Rosenberg M, Wang Z, Chuang SL, Shoemaker CF (1995) Viscoelastic property changes in cheddar cheese during ripening. J Food Sci 60: 640-644. doi:10.1111/j.1365-2621.1995.tb09846.x

Saldamli I, Kaytanli M (1998) Utilisation of fromase, maxiren and rennilase as alternative coagulating enzymes to rennet in Turkish white cheese production. Milchwissenschaft 53: 22-25

Sert D, Ayar A Akin N (2007) The effects of starter culture on chemical composition, microbiological and sensory characteristics of Turkish Kasar cheese during ripening. Milk. Int J Dairy Technol 60: 245252. doi: 10.1111/j.1471-0307.2007.00339.x

Singh TK, Drake MA, Cadwallader KR (2003) Flavor of cheddar cheese: A chemical and sensory perspective. Compr Rev Food Sci Food Saf 2:139-162. doi:10.1111/j.1541-4337.2003.tb00021.x

Sousa MJ, Ardo Y, Mcsweeney PLH (2001) Advanced in the study of proteolysis during cheese ripening. Int Dairy J 11: 327-345. doi: 10.1016/S0958-6946(01)00062-0

Tarakci Z, Durmaz H, Sagun E (2005) The effect of siyabo (Ferula sp.) on ripening of herby cheese. Yüzüncü Yil Uni J Agric Sci 15: 53-56

Tarakci Z, Kucukoner E (2006) Changes on physicochemical and proteolysis of vacuum-packed Turkish kasar cheese during ripening. J Central European Agric 7: 459-464
Tavaria F, Franco I, Carballo FJ, Malcata FX (2003) Amino acid and soluble nitrogen evolution throughout ripening of Serra da Estrela cheese. Int Dairy J 13: 537-545. https://doi.org/10.1016/S09586946(03)00060-8

Tekinsen C (1996) Dairy Products Technology. Konya: Selçuk Uni Vet Med Fac Publ, pp 326

Turkoglu H, Ceylan ZG, Dayisoylu KS (2003) The microbiological and chemical quality of orgu cheese produced in Turkey. Pakistan J Nutr 2: 92-94. doi: 10.3923/pjn.2003.92.94

Ucuncu M (2004) Milk and dairy products technology. Meta Press, Izmir, Turkey, pp 571

Uysal S (2008) Investigation of the possibility of using natural thermophilic whey culture in the dil cheese production, M.Sc. Thesis submitted to Science Institute (Harran University), Sanliurfa, Turkey

Walstra P, Jennees R (1984) Dairy Chemistry, Physics. Aion, New York: Wiley Interscience Publ, pp 467

WTO (2019). World Trade Organisation. https://www.wto.org/english/ res_e/publications_e/trade_profiles17_e.htm. Accessed 30 January 2019.

Yazici F, Dervisoglu M (2003) Effect of pH adjustment on some chemical, biochemical, and sensory properties of Civil cheese during storage. J Food Engin 56:361-369. https://doi.org/10.1016/S02608774(02)00208-X

Yildiz N, Bircan H (1994) The Methodology of research and trial. Atatürk Uni Agric Fac Publ, Erzurum, Turkey, pp 266

Yilmaztekin M (2001) A Research on the utilization possibilities of Lactobacillus acidophilus and Bifidobacterium bifidum in white cheese production, M.Sc. Thesis submitted to Science Institute (Harran University), Sanliurfa, Turkey 